\title{
A Newly Recorded Species of the Genus Milisipepsis (Lepidoptera, Sesiidae) from Korea
}

\author{
Cheol Min Lee, Yutaka Arita ${ }^{1}$ and Yang-Seop Bae ${ }^{2 *}$ \\ Division of Forest Ecology, Korea Forest Research Institute, 57 Hoegi-ro, Dongdaemun-gu, Seoul 130-712, Korea \\ ${ }^{1}$ Zoological Laboratory, Faculty of Agriculture, Meijo University, Tempaku-ku, Nagoya 468-8502, Japan \\ ${ }^{2}$ Division of Life Sciences, College of Natural Science, University of Incheon, Incheon 406-840, Korea

\section{한국산 유리나방과 Milisipepsis 속의 미기록종 보고}

\author{
이철민 $\cdot$ 아리타 유타카 ${ }^{1} \cdot$ 배양섭 $^{2 *}$ \\ 국립산림과학원 산림생태연구과, ${ }^{1}$ 메이조대학교 농학부, ${ }^{2}$ 인천대학교 생명과학부
}

\begin{abstract}
The genus Milisipepsis is reported for the first time in Korea with M. takizawai (Arita and Špatenka, 1989). Description, image of the adult, female genitalia, and Korean common name of the species are provided in this paper.
\end{abstract}

Key words: Sesiidae, Milisipepsis, Genitalia, Korea

초 록: Milisipepsis속은M. takizawai (Arita and Špatenka, 1989)에 의해서 한국에서 처음으로 기록된다. 기재, 성충사진, 암컷 생식기와 국명 을 제시한다.

검색어: 유리나방과, Milisipepsis, 생식기, 한국

The genus Milisipepsis has hitherto been recorded with two species in the eastern and south-eastern Palaearctic region and at least five species in the Oriental region (Špatenka et al., 1999). Morphologic features of this genus are similar to wasps because 1st and 2nd abdominal segments are smaller and narrower than the other segments (Arita and Špatenka, 1989). Milisipepsis takizawai (Arita and Špatenka, 1989) is distributed in southern Primorye of the Russian Far East and in Japan. Larva of this species is a borer of twigs of Betula platyphylla Sukatchev var. japonica (Miquel) Hara and B. ermanii Chamisso, Betulaceae (Arita, 1990). In the present study, Milisipepsis takizawai is newly recorded in Korea. Also, the female adult with its genitalia is described and illustrated.

*Comesponding author: baeys@incheon.ac.kr

Received November 14 2011; Revised November 25 2011; Accepted December 52011

\section{Materials and Methods}

Terminology used in descriptions of morphology follows Špatenka et al. (1999). Female genitalia was dissected after being macerated for 4-6 min in $10 \% \mathrm{KOH}$ heated in a double waterbath. All figures and measurements (in millimeters) were made using a binocular microscope. Photographs of adults were taken with a Cannon 450D digital camera. Abbreviations used in this paper to indicate the collection and provincial names are as follows: GW, Gangweon-do; GN, Gyeonsannam-do; UIB, University of Incheon.

\section{Taxonomic account}

Milisipepsis takizawai (Arita and Špatenka, 1989) 가는허리유리나방(신칭)

Korean name: Ga-neun-heo-ri-yu-ri-na-bang (Figs. 1-2) 


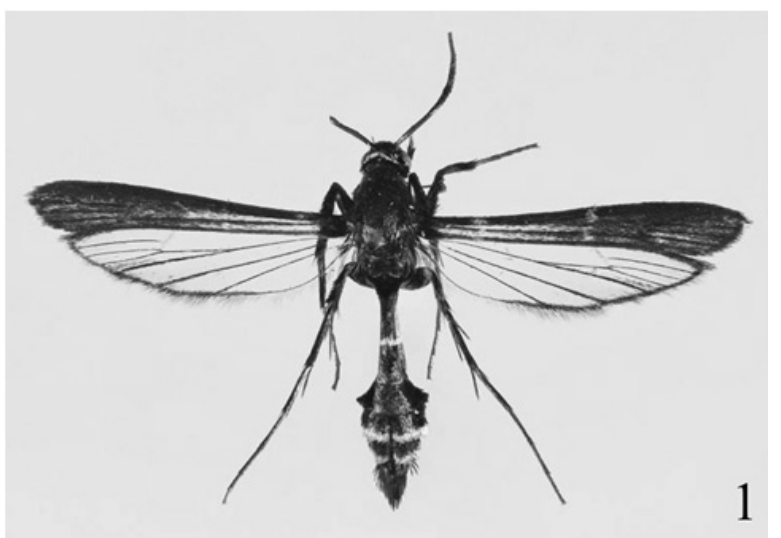

Fig. 1. Milisipepsis takizawai (Arita and Špatenka). 1, Female adult.

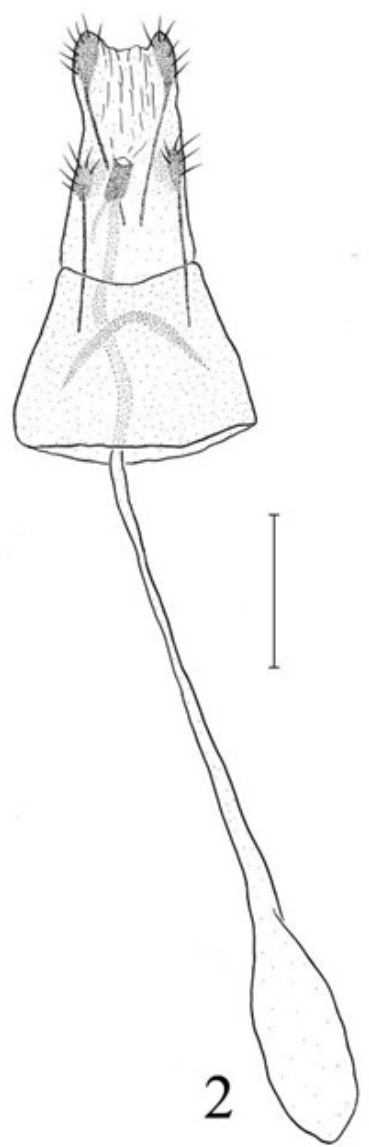

Fig. 2. Female genitalia of Milisipepsis takizawai (Arita and Špatenka). SL. No. UIB-5561. Scale bar $=1.0 \mathrm{~mm}$.

Similipepsis takizawai Arita and Špatenka, 1989, Jpn. J. Ent. 57: 61, figs. 1-10.

Diagnosis. This species is similar to M. yunnanensis, but can be easily separated from the latter by the presence of the anterior and posterior transparent areas of the forewing, which are absent in M. yunnanensis.

Description. Female (Fig. 1). Wingspan, $18 \mathrm{~mm}$; body length 12 $\mathrm{mm}$; forewing $8 \mathrm{~mm}$. Head: antenna dark fuscous; frons deeply grey with a golden sheen; labial palpus pale yellowish grey; basal segment with apical half dark fuscous; median segment with lower apical tip white; terminal segment mixed white scales; vertex rather appressed, black with a purple-blue sheen, the lateral side posteriorly with orange scales; occipital fringes black. Thorax: patagia black with green sheen; tegulae black with bluish sheen; mesothorax and metathorax black with bluish sheen; thorax laterally black with bluish sheen. Legs: neck plate black with bluish sheen; fore coxa black with bluish sheen, with a few dark brown scales; fore femur black to dark brown with bluish sheen; fore tibia dark brown with bluish sheen, with a narrow and dark yellow strip ventrally; fore tarsus dark brown dorsally, with dark yellow ventrally; mid coxa and mid femur black with bluish sheen; mid tibia black with bluish sheen, with a few dark yellow scales ventrally; mid tarsus dark brown with bluish sheen, with dark yellow ventrally; hind coxa black with bluish sheen, with white scales interior-ventrally; hind femur black with bluish sheen, with a few dark yellow scales ventrally; hind tibia black with bluish sheen, with a few dark brown scales at base of both pairs of spurs with yellowish sheen; hind tarsus dark brown with bluish sheen, with a few yellow scales. Forewing: dark brown with a purplish sheen; anterior transparent area and posterior transparent area forming narrow longitudinal hyaline stripes; discal spot dark; cilia dark grey. Hindwing hyaline, veins and very narrow terminal edge dark brown; posterior half between veins $\mathrm{Cu} 1$ and $\mathrm{Cu} 2$ with sparsely dark brown scale; cilia dark grey. Abdomen: black with bluish sheen; 1st segment slightly narrowed posteriorly, 2nd extremely depressed with orange segmental margin, 3rd slightly expanded, 4th and 5th largely expanded, and 2nd, 3rd, 6th and 7 th narrowed posteriorly with orange segmental margins, respectively; on ventral side 2nd segment snow-white, 3rd dull white with snow-white segmental margin, 6th with orange segmental margin; anal tuft black.

Female genitalia (Fig. 2). Papilla analis relatively short with short hairs; posterior and anterior apophysis of about equal length; ostium bursae small, cup-shaped, opening at middle of 
intersegmental membrane between 7th and 8th abdominal segments; antrum small, short, cylindrical; ductus bursae very long, narrow, very gradually dilated into corpus bursae, which is small and linear-oblong; signum absent.

Material examined. GW: 1 ㅇ, Mt. Bohwa-san, Gajeong-ri, 21 VI 2003 (H.Y. Oh), gen slide no. UIB-5561; GN: 1 우, Mt. Jiri-san, Sancheng-gun, 25-29 VI 2001 (UIB).

Distribution. Korea (GW, GG); Russian Far East (Southern Primorye); Japan (Hokkaido, Honshu).

Host plants. Betula platyphylla Sukatchev var. japonica (Miquel) Hara and B. Ermanii Chamisso (Betulaceae) (Špatenka et al., 1999).

\section{Acknowledgments}

We wish to express our sincere thanks to Mr. Y.H. Oh (Chuncheon, Korea) for a loan of specimens. This research was supported partly by the project on survey and excavation of Korean indigenous species of the National Institute of Biological Resources (NIBR) under the Ministry of Environment, Korea. This work was supported in part by University of Incheon Research Grant in 2007.

\section{Literature Cited}

Arita, Y. 1990. Descriptions of the larva and pupa of Similipepsis takizawai Arita \& Špatenka (Lepidoptera, Sesiidae). Nota lepid. 13 (4): 192-197.

Arita, Y. and K. Špatenka. 1989. A new species of Similipepsis (Lepidoptera, Sesiidae) from Japan. Jpn. J. Ent. 57 (1): 61-66.

Špatenka, K., O. Gorbunov, Z. Laštuvka, I. Toševski and Y. Arita. 1999. Handbook of Palearctic Macrolepidoptera, Volume 1 Sesiidae - Clearwing Moths. 569 pp. Gem Publ. Co., Wallingford. 